\title{
"Tax aggressiveness and CEO overconfidence in the stock market: Evidence from Brazil"
}

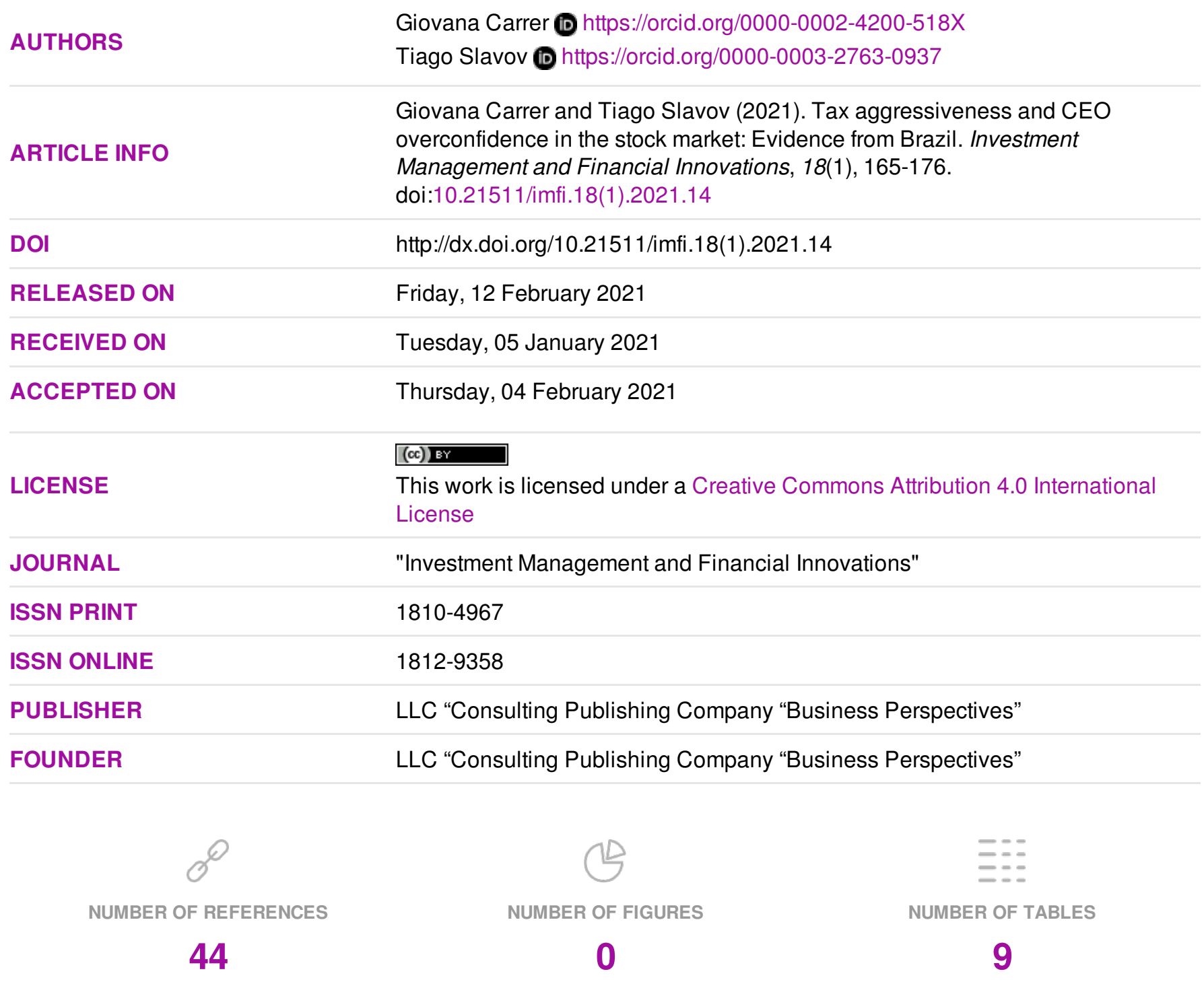

(c) The author(s) 2022. This publication is an open access article. 


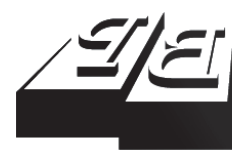

\section{BUSINESS PERSPECTIVES}

(O)

LLC "CPC "Business Perspectives" Hryhorii Skovoroda lane, 10 Sumy, 40022, Ukraine www.businessperspectives.org
Received on: $5^{\text {th }}$ of January, 2020 Accepted on: $4^{\text {th }}$ of February, 2021 Published on: $12^{\text {th }}$ of February, 2021

(C) Giovana Carrer, Tiago Slavov, 2021

Giovana Carrer, M.S., Professor, Centro Universitário FECAP, Brazil.

Tiago Slavov, Researcher and Lecturer Master's in Accounting, Accounting Department, Centro Universitário FECAP, Brazil. (Corresponding author)
TAX AGGRESSIVENESS

AND CEO OVERCONFIDENCE
IN THE STOCK MARKET:
EVIDENCE FROM BRAZIL

\begin{abstract}
This study examines the association between tax aggressiveness and overconfidence in 277 Brazilian stock market listed companies from 2010 to 2017, with the supposition (based on optimal capital ownership structure theory) that the greater a manager's overconfidence, the more aggressive the company's tax decisions. Overconfidence is measured in an innovative way in which normalizing excess acquisitions and excess investments using the company's market value and then combining these two variables with indebtedness to capture, more directly, the possible effects of overconfidence on the corporation's operations. Tax aggressiveness is computed using a tax burden on earnings and value-added. The variables included in the model were obtained from data contained in the selected companies' financial statements. Data analysis was performed by multiple linear regression. The parameters used combined and fixed effects methods to identify an association between tax aggressiveness and overconfidence. Data related to corporate governance, CEO's characteristics, and capital concentration were used as control variables. The study's main finding does not show any significant relationship between fiscal aggressiveness and overconfidence; however, they did show a significant association with tax aggressiveness, the company's size, the return on shares, and the education level of the $\mathrm{CEO}$. An interesting finding of the robustness tests is the stationarity of tax aggressiveness, which could partially explain the non-significance of the main finding.
\end{abstract}

\section{Keywords}

tax aggressiveness, overconfidence, capital structure, agency costs, corporate governance, behavioral finance

JEL Classification H26, G32, G40

\section{INTRODUCTION}

Tax aggressiveness is influenced by issues related to the separation of ownership and control (Slemrod, 2004). In general, shareholders expect managers who act on their behalf to focus on maximizing profits, including taking actions that result in reduced tax liabilities. However, the separation between ownership and control can generate corporate tax decisions that reflect an administrator's private interests (Hanlon \& Heitzman, 2010).

Separation of ownership and control, a context in which owners delegate the power of decisions about their assets to a third party (Berle \& Means, 1991), causes conflicts of interest. Because an agent does not necessarily make decisions compatible with the principal's interests, formalized compensation contracts to align the interests of the two parties are required, which generates agency costs. Agency costs are incurred to address issues related to ownership structure, management incentives, corporate governance, and the characteristics of the organization's chief executive (Wilde \& Wilson, 2018).

Overconfidence is considered one of the characteristics that lead company managers to develop greater tax aggressiveness (Hsieh et al., 
2018). In Brazil and other developing stock markets, issues of overconfidence are recurrent in corporate governance studies. Considering the level of taxation in developing markets, the immediate assumption is that tax aggressiveness in Brazil is positively associated with overconfidence (Jensen \& Meckling, 1976).

This study examines whether the manager's overconfidence characteristic explains the tax aggressiveness in Brazilian companies that trade shares on the stock exchange.

\section{LITERATURE REVIEW}

Jensen and Meckling's (1976) theory of optimal capital ownership structure is adopted as the basis for this study's development. This theory predicts that corporate governance mechanisms will align the interests of managers and investors. In the context of this study, tax aggressiveness would result from managerial behaviors that conflict with investors' interests since reducing the tax burden on the company's operations could destroy the firm's value in the long run. Therefore, this study hypothesizes is that managerial overconfidence will result in greater tax aggressiveness in the sample companies.

\subsection{Determinants of tax aggressiveness}

A conceptual structure distinguishes categories of tax aggression determinants: a) implementation costs; b) costs of results; and c) agency costs. Agency costs are those associated with minimizing the conflicts of interest between executives and shareholders generated by the separation of capital and property, such as the firm's ownership structure, management incentives, corporate governance, and executive characteristics (Wilde \& Wilson, 2018).

The costs associated with tax aggressiveness may differ depending on a firm's ownership structure; for example, the costs are less than the benefits for family businesses in a concentrated property environment. Thus, it is expected that there will be a higher level of tax aggressiveness in family businesses. For public companies, the benefits seem greater than the associated costs, so public companies are expected to be tax aggressive. Finally, multinational companies generally pay low taxes in their host countries (Annuar et al., 2014).
Also, companies that compensate their managers with incentives based on performance after taxes tend to be more tax aggressive (Hanlon \& Heitzman, 2010). In contrast, companies with higher internal controls levels are expected to be less prone to tax aggressiveness (Desai \& Dharmapala, 2006).

Executive characteristics can be directly or inversely associated with tax aggressiveness. The studies indicate that executive characteristics as determinants of tax aggressiveness include military experience, narcissism, political orientation, personal aggressiveness, gender, religious norms in the community, power managers, and managerial capacity (Law \& Mills, 2017; Olsen \& Stekelberg, 2016; Christensen et al., 2015; Chyz, 2013; Francis et al., 2014; Boone et al., 2013; Dyreng et al., 2012; Feller \& Schanz, 2017; Koester et al., 2017).

\subsection{Overconfidence}

Overconfidence is defined as an optimistic estimate of one's own abilities and the results related to one's situation, thus characterizing the "better than average" effect (Langer, 1975). In general, individuals overestimate their ability to control results and underestimate the probability of failure (Alicke et al., 1995; Langer, 1975; March \& Shapira, 1987; Weinstein, 1980).

Chen, Leung, Song, and Goergen (2019) confirm the assumption that female directors are associated with less aggressive investment policies, better acquisition decisions, and better financial performance for companies operating in sectors where overconfidence is prevalent. Chen et al. (2020) find a positive relationship between CEO overconfidence and cash value; that is, the more overly confident the CEO, the higher the firm's cash value. Hwang, H. Kim, and T. Kim (2020) confirm the findings of previous studies that their over- 
confidence can drive the mergers and acquisitions of overly confident CEOs. Gietl and Kassner (2020) study the association between managerial overconfidence and limited banking responsibility. Their main result is that managerial overconfidence requires intervention in the payment of short-term bonuses. This is due to the bank's exploitation of the bonus manager's overvaluation, which causes excessive risk-taking in balance and is amplified by government guarantees. Banerjee, Dai, Humphery-Jenner, and Nanda (2020) show that companies with overconfident executives tend to hire internally; besides, when companies hire internally, they are more likely to choose a more confident candidate. Tseng and Demirkan (2020) investigate the joint impact of CEO overconfidence and corporate social responsibility on companies' cost of equity. The study shows that in companies with more overconfident CEOs, investors charge lower capital costs if corporate social responsibility activities involve less managerial discretion.

\subsection{Overconfidence and tax aggressiveness}

Chyz, Gaertner, Kausar, and Watson (2015) investigated 135 companies between 1997 and 2007. The authors used CASHETR, TAX SHELTER, and $B T D$ as their tax measures. The overconfidence measure used in this research was based on Malmendier and Tate (2005) who classified executives as overconfident when their stock options exceeded $67 \%$ of the average value of stock options. The results confirm the theoretical prediction of an association between tax aggressiveness and overconfidence, demonstrating a strong relationship between the variables.

Aliani, Mhamid, and Rossi (2016) investigated a sample of 28 listed companies in Tunisia from 2001 to 2011. The tax aggressiveness measure used in their survey was the ETR, and the overconfidence measure used was composed using executive responses to a questionnaire. The results show robust evidence of a positive relationship between $\mathrm{CEO}$ overconfidence and the propensity to minimize corporate taxes.

Kubick and Lockhart (2017) attribute overconfidence to CEOs based on press releases and meas- ure tax aggressiveness using a SHELTER metric. The researchers investigate whether CEOs who are chosen to receive awards from leading media outlets adopt more aggressive tax policies. The results suggest that CEO overconfidence has a significant impact on corporate fiscal policy.

Gul, Khedmati, and Shams (2018) use a sample of 11,327 mergers and acquisitions that took place between 1991 and 2015 to investigate the alleged association between acquisitions and tax aggressiveness. In this research, CASHETR, CASHETRLT, GAAP ETR, GAAP ETRLT, SHELTER are used as tax aggressiveness metrics. The authors classify CEOs as overconfident if they hold more than a total of the cash options twice or more during the sample period. They find that companies with operations of this nature have lower tax payments and that overconfidence can influence tax aggressiveness.

Anjani (2018) used a sample of 172 companies listed on the Indonesian Stock Exchange from 2013 to 2016. The tax aggressiveness measure used was the ETR, and overconfidence was determined based on the capital spent to acquire capital goods. Research has shown that overconfidence has a significant effect on tax aggressiveness.

Hsieh et al. (2018) argue that the interaction between CEOs and CFOs favors tax aggressive activities because the CEO exercises power over the executive board. The CFO has the technical knowledge about the company's operations and tax reduction opportunities provided in the legislation. In this research, CEOs and CFOs were considered overconfident if they exhibited net buying behavior of their company's shares more than $50 \%$ of the time during the sample period. ETR and CASHETR were used to measure tax aggressiveness. The results indicate that companies are more likely to engage in tax aggressive activities when they have overconfident CEOs and CFOs.

According to the literature, this study tests the hypothesis:

H1 Overconfidence is positively associated with tax aggressiveness. 


\section{METHODS}

The data were analyzed using panel data analysis, respecting all premises and specifications appropriate for the examined corporations. Also, tests were carried out to verify the consistency of the results obtained. In all cases, the coefficients obtained were controlled using the traditional determinants found in finance studies.

The sample of companies is composed of 277 Brazilian companies listed on the B3 Stock Exchange, excluding financial institutions. The variables included in the model were obtained from data contained in the selected companies' financial statements. The dependent and independent variables are composed using financial data collected from the Economatica ${ }^{\infty}$ database. The control variables, except market to book, size, and return, are composed of non-financial data collected from the ComDinheiro database.

The effective tax rate $(E T R)$ is calculated by dividing tax expense by earnings before taxes (Armstrong et al., 2012). The cash effective tax rate (CASHETR) measures the effective cash taxes paid during the year instead of using the tax expense measured on an accrual basis (Dyreng et al., 2008).

Metrics of tax aggressiveness that only measure the impact of taxes on income can limit the results in a hypothesis where indirect taxation exists, as is the case in Brazil. Thus, the CTAadj measure includes direct taxes, calculated on earnings, and indirect taxes, calculated on aggregate values. The measure uses the division between total taxes and contributions, disclosed in the Value-Added Statement (DVA), and the company's gross revenue, also disclosed in the DVA (Ignacio, 2018).
The overconfidence variable proposed in this study is based on the measure created by Schrand and Zechman (2012). In this study, excess acquisitions and excess investments are normalized using the company's market value; these two variables were then combined with indebtedness.

The control variables selected for the tax aggressiveness model are those related to agency conflicts that arise from the separation of ownership and control: corporate governance, ownership structure, the concentration of capital, and executive characteristics.

The variables Family, Government, and ForeignCapital represent companies controlled by members of a family, the government, and international investors, respectively. MainShareholder indicates the control is concentrated in the main shareholder. FEM indicates that the company's $\mathrm{CEO}$ is female. Executive education is indicated by the variables Graduation, MBA, MSc, and Ph.D., referring to undergraduate degree, master's degree in business administration, master's degree, and doctorate. CEO_Duality indicates whether the CEO is a company founder, and CEO_Turnover represents the length of time the $\mathrm{CEO}$ has been in office.

\section{RESULTS}

\subsection{Descriptive statistics}

The descriptive statistics of the variables and their correlations, found in this section, are followed by the model estimation results.

Table 2 reports that the average values of the tax aggressiveness variables CASHETR, ETR, and

Table 1. Model variables

\begin{tabular}{|c|c|c|}
\hline Variable type & Name & Definition \\
\hline \multirow{3}{*}{ Dependent } & Cash effective tax rate (CASHETR) & $\frac{\text { Income taxes payable + Income tax expense }}{\text { Earnings before income taxes }}$ \\
\hline & Effective tax rate (ETR) & $\frac{\text { Income tax expense }}{\text { Earnings before income taxes }}$ \\
\hline & Aggregate tax cost (CTAadj) & $\frac{\text { Taxes on value-added }}{\text { Gross revenue on the statement of added value }}$ \\
\hline \multirow{2}{*}{ Independent } & \multirow{2}{*}{ Overconfidence } & Over investment Over acquisition Dept \\
\hline & & $\overline{\text { Equity }}$ \\
\hline
\end{tabular}


Table 2. Descriptive statistics

\begin{tabular}{|c|c|c|c|c|c|}
\hline Variables & Mean & Median & Standard deviation & Minimum & Maximum \\
\hline CASHETR & 0.1286 & 0.08188 & 1.513 & -8.764 & 45.6 \\
\hline ETR & 0.2817 & 0.195 & 2.836 & -16.12 & 97.66 \\
\hline CTAadj & 0.2019 & 0.098 & 1.007 & -5.757 & 24.03 \\
\hline OverConfidence & 0.007287 & 0.0000 & 0.04734 & 0.0000 & 1.321 \\
\hline $\mathrm{MB}$ & 1.514 & 0.8100 & 3.927 & -27.13 & 72.32 \\
\hline Size & 14.05 & 14.58 & 2.934 & -0.4050 & 20.62 \\
\hline Return & 1.184 & 0.0000 & 43.53 & -1.000 & 1.749 \\
\hline
\end{tabular}

CTAadj are $12.86 \%, 28.17 \%$, and $20.19 \%$, respectively, indicating that the effective tax burden of the companies in the sample varies from $12.86 \%$ to $28.17 \%$. Thus, considering that the nominal tax burden in Brazil is 34\%, as stated by França and Monte (2018), it can be concluded that, in general, the Brazilian companies in the sample are tax aggressive. This conclusion confirms the results of Martinez and Salles (2018) who find tax aggressiveness in their sample of 213 Brazilian companies between 2010 and 2015 .

Overconfidence was measured using a variable created in this study based on a consolidation of measures in the literature (Schrand \& Zechman, 2012) that represents a manager's behavior toward projects with a certain level of risk. The study's innovation is normalizing excess acquisitions and excess investments using the company's market value and then combining these two variables with indebtedness. Thus, the measure obtained represents, in a more direct way, the possible effects of overconfidence on a firm's operations. Instead of discarding corporations below the median, in two of the three measures, the innovative overconfidence variable allows obtaining its proportion compared to the company's assets' total market value. On average, the results show overconfidence represented $0.07 \%$ of assets.

All models included controls for traditional finance variables that correspond to significant differences between corporations (Titman \& Wessels, 1988). The set of growth opportunities, represented by the $M B$ variable, averaged 1.51 . The average size of the companies, represented by the variable Size, was 14.05. The return on shares, represented by the variable Return, averaged 1.18.

Table 3 shows the analysis of the ownership concentration variables suggesting similar proportions of family and foreign companies in the sample of $13.38 \%$ and $12.20 \%$, respectively, with public companies representing about $5.50 \%$ of the sample. Besides, less than $50 \%$ of the companies have the main shareholder. These results seem to indicate a sample composed of professional companies whose capital is dispersed.

As for personal characteristics, just over 3\% of the observations used in the data sample have female CEOs. This confirms the result of another study by Dalcero, Fabrício, and Ferreira (2020) that investigates the influence of gender on accrual quality, which indicated approximately $3 \%$ of CEOs in a

Table 3. Statistics of variables used in the robustness tests

\begin{tabular}{|c|c|c|c|c|c|}
\hline Variables & Mean & Median & Standard deviation & Minimum & Maximum \\
\hline Family & 0.1338 & 0.0000 & 0.3405 & 0.0000 & 1.000 \\
\hline Government & 0.05509 & 0.0000 & 0.2282 & 0.0000 & 1.000 \\
\hline ForeignCapital & 0.1220 & 0.0000 & 0.3274 & 0.0000 & 1.000 \\
\hline MainShareholder & 47.87 & 44.48 & 30.87 & 0.0000 & 100.0 \\
\hline FEM & 0.03247 & 0.0000 & 0.1773 & 0.0000 & 1.000 \\
\hline Graduate & 0.9238 & 1.000 & 0.2653 & 0.0000 & 1.000 \\
\hline MBA & 0.5053 & 1.000 & 0.5001 & 0.0000 & 1.000 \\
\hline $\mathrm{MSc}$ & 0.1175 & 0.0000 & 0.3221 & 0.0000 & 1.000 \\
\hline Ph.D. & 0.02243 & 0.0000 & 0.1481 & 0.0000 & 1.000 \\
\hline CEO_Duality & 0.05667 & 0.0000 & 0.2313 & 0.0000 & 1.000 \\
\hline CEO_Turnover & 0.5858 & 1.000 & 1.095 & -6.000 & 4.000 \\
\hline
\end{tabular}


sample of 170 Brazilian companies listed on the B3 Stock Exchange were women. Approximately 92\% of the observations have CEOs with higher education levels. Of these, around $50 \%$ attained an MBA, more than $11 \%$ achieved a master's degree, and just over $2 \%$ earned a doctorate.
An analysis of the correlations shown in Table 4 indicates no strong linear association between the variables used in the tax aggressiveness model and overconfidence and between the variables used in the robustness tests. Such results suggest the possibility of no significance between the

Table 4. Correlation matrix

\begin{tabular}{|c|c|c|c|c|}
\hline & CASHETR & ETR & CTAadj & OverConfidence \\
\hline CASHETR & 1.0000 & 0.4082 & 0.0097 & -0.0089 \\
\hline ETR & & 1.0000 & -0.0067 & -0.0111 \\
\hline CTAadj & & & 1.0000 & -0.0088 \\
\hline \multirow[t]{2}{*}{ OverConfidence } & & & & 1.0000 \\
\hline & MB & Size & Return & Family \\
\hline CASHETR & 0.0187 & 0.0058 & 0.0009 & -0.0143 \\
\hline ETR & 0.0159 & 0.0211 & -0.0008 & -0.0204 \\
\hline CTAadj & 0.0088 & -0.0152 & 0.0006 & -0.0331 \\
\hline OverConfidence & -0.0044 & 0.0768 & -0.0051 & -0.0500 \\
\hline $\mathrm{MB}$ & 1.0000 & 0.1164 & -0.0009 & -0.0468 \\
\hline Size & & 1.0000 & -0.0159 & -0.1810 \\
\hline Return & & & 1.0000 & -0.0107 \\
\hline \multirow[t]{2}{*}{ Family } & & & & 1.0000 \\
\hline & Government & ForeignCapital & MainShareholder & FEM \\
\hline CASHETR & -0.0279 & -0.0007 & 0.0144 & 0.0015 \\
\hline ETR & -0.0180 & -0.0191 & -0.0282 & -0.0010 \\
\hline CTAadj & -0.0003 & 0.0066 & -0.0137 & -0.0137 \\
\hline OverConfidence & 0.0361 & -0.0075 & -0.0414 & -0.0192 \\
\hline $\mathrm{MB}$ & -0.0423 & -0.0055 & -0.0346 & -0.0254 \\
\hline Size & 0.1677 & 0.0014 & -0.3288 & -0.0137 \\
\hline Return & -0.0070 & -0.0086 & 0.0468 & -0.0072 \\
\hline Family & -0.0958 & -0.1482 & -0.1672 & 0.0127 \\
\hline Government & 1.0000 & -0.0925 & 0.0748 & 0.1250 \\
\hline ForeignCapital & & 1.0000 & -0.0422 & -0.0535 \\
\hline MainShareholder & & & 1.0000 & 0.0079 \\
\hline \multirow[t]{2}{*}{ FEM } & & & & 1.0000 \\
\hline & Graduate & MBA & MSc & Ph.D. \\
\hline CASHETR & 0.0039 & -0.0279 & -0.0294 & -0.0192 \\
\hline ETR & 0.0077 & 0.0213 & 0.0419 & 0.0049 \\
\hline CTAadj & 0.0157 & -0.0225 & -0.0069 & 0.0281 \\
\hline OverConfidence & 0.0120 & 0.0043 & 0.0403 & -0.0106 \\
\hline $\mathrm{MB}$ & -0.0413 & 0.0195 & -0.0232 & 0.0071 \\
\hline Size & 0.1586 & 0.2621 & 0.1377 & 0.0584 \\
\hline Return & 0.0083 & -0.0210 & 0.0000 & -0.0054 \\
\hline Family & -0.1506 & -0.2072 & -0.1344 & -0.0639 \\
\hline Government & 0.0731 & 0.0244 & 0.0855 & 0.0565 \\
\hline ForeignCapital & 0.0614 & -0.0326 & 0.0265 & 0.0781 \\
\hline MainShareholder & -0.0236 & 0.0412 & 0.0719 & 0.0732 \\
\hline FEM & -0.1854 & -0.0604 & -0.0057 & -0.0282 \\
\hline Graduate & 1.0000 & 0.2946 & 0.1064 & 0.0441 \\
\hline MBA & & 1.0000 & 0.3613 & 0.1499 \\
\hline MSc & & & 1.0000 & 0.4149 \\
\hline \multirow{2}{*}{ Ph.D. } & & & & 1.0000 \\
\hline & CEO Duality & CEO Turnover & & \\
\hline CASHETR & 0.0130 & -0.0069 & & \\
\hline ETR & -0.0076 & -0.0401 & & \\
\hline CTAadj & -0.0113 & 0.0219 & & \\
\hline OverConfidence & -0.0298 & 0.0151 & & \\
\hline MB & 0.0449 & -0.0008 & & \\
\hline Size & -0.0762 & -0.1197 & & \\
\hline Return & -0.0117 & 0.0068 & & \\
\hline Family & 0.1271 & 0.0568 & & \\
\hline Government & -0.0669 & -0.1116 & & \\
\hline ForeignCapital & 0.0043 & 0.0130 & & \\
\hline MainShareholder & -0.1313 & 0.0138 & & \\
\hline FEM & -0.0456 & 0.0023 & & \\
\hline Graduate & 0.0522 & -0.0623 & & \\
\hline MBA & -0.1176 & -0.0516 & & \\
\hline $\mathrm{MSc}$ & -0.0908 & -0.0306 & & \\
\hline Ph.D. & -0.0377 & -0.0269 & & \\
\hline CEO Duality & 1.0000 & 0.0282 & & \\
\hline CEO Turnover & & 1.0000 & & \\
\hline
\end{tabular}


variables of the model that investigates the supposed association between tax aggressiveness and overconfidence.

The correlations between the variables CASHETR, ETR, and CTAadj and OverConfidence are low, indicating no association between tax aggressiveness and overconfidence.

The corporate governance variables Market to book, Size, and Return even show low correlation with the tax aggressiveness and overconfidence variables; this seems to make sense regarding the trend of expectations in the literature. The ownership concentration variables confirm the expectation that family and public companies are more tax aggressive. CASHETR and ETR confirm the expectation that foreign companies pay less tax in host countries.

The ETR and CTAadj measures support the expectation that female executives are less tax aggressive. The levels of MBA and MSc training confirm the expectation that a higher level of knowledge results in lower taxation for the variables CASHETR and CTAadj. The variable CEO_Duality tends to reverse for ETR and CTAadj, meaning that there could be greater tax aggressiveness if the executive is the company's founder. Finally, the $C_{E}$
Turnover variable has a reverse trend in the ETR tax measure, meaning that higher executive turnover decreases the tax burden, representing greater aggressiveness in the payment of taxes.

\subsection{Tax aggressiveness and overconfidence}

The analysis in Table 5 shows that overconfidence does not explain tax aggressiveness for any of the measures used - CASHETR, ETR, and CTAadjsince the OverConfidence variable is not significant in any of the models presented.

\subsection{Robustness tests}

To verify the consistency of the non-significance observed in the main model, the other specifications examined internal variables that could influence the tax aggressiveness of the sample corporations, including the personal characteristics of managers, capital concentration, and CEO duality and turnover.

\subsubsection{Personal characteristics of CEOs}

Table 6 presents the results of the models, including the variables corresponding to CEO characteristics.

Table 5. Tax aggressiveness and overconfidence

\begin{tabular}{|c|c|c|c|c|c|c|}
\hline \multirow{2}{*}{ Variables } & \multicolumn{2}{|c|}{ CASHETR } & \multicolumn{2}{|c|}{ ETR } & \multicolumn{2}{|c|}{ CTAadj } \\
\hline & Coefficient & $p$-value & Coefficient & $p$-value & Coefficient & $p$-value \\
\hline OverConfidence & -0.251695 & 0.2524 & -0.238253 & 0.3918 & 0.140414 & 0.5509 \\
\hline Market to book & 0.00617826 & 0.2029 & 0.00590853 & 0.6184 & 0.00057009 & 0.7485 \\
\hline Size & -0.0117062 & 0.5486 & 0.122824 & 0.2663 & -0.156105 & $0.0166^{* *}$ \\
\hline Return & 1.06596E-05 & 0.6636 & 0.000256317 & $5.94 \mathrm{E}-35 * * *$ & 9.24920E-05 & $4.26 \mathrm{E}-12 * * *$ \\
\hline
\end{tabular}

Note: $* * 1 \%<p$-value $<5 \% ; * * *$-value $<1 \%$.

Table 6. Personal characteristics

\begin{tabular}{|c|c|c|c|c|c|c|}
\hline \multirow{2}{*}{ Variables } & \multicolumn{2}{|c|}{ CASHETR } & \multicolumn{2}{|c|}{ ETR } & \multicolumn{2}{|c|}{ CTAadj } \\
\hline & Coefficient & $p$-value & Coefficient & $p$-value & Coefficient & $p$-value \\
\hline Const & 0.0586611 & 0.8770 & -1.95526 & 0.3891 & 2.27325 & $0.002 * * *$ \\
\hline OverConfidence & -0.307690 & 0.2446 & 0.848424 & 0.4033 & 0.220181 & 0.4403 \\
\hline FEM & 0.0429275 & 0.6160 & 0.205988 & 0.6279 & -0.0331542 & 0.4041 \\
\hline Graduate & 0.17592 & 0.3843 & -0.618430 & 0.1896 & -0.00338418 & 0.9478 \\
\hline MBA & -0.135819 & 0.4148 & 0.469016 & 0.2632 & 0.0342921 & 0.4268 \\
\hline MSc & -0.0966002 & 0.5045 & 1.84487 & 0.3194 & -0.0463136 & 0.4449 \\
\hline Ph.D. & -0.0993213 & 0.6485 & -1.41792 & 0.3205 & 0.264125 & $0.0379 * *$ \\
\hline $\mathrm{MB}$ & 0.00734917 & 0.1161 & 0.0113541 & 0.4708 & 0.00102175 & 0.5566 \\
\hline Size & 0.00045256 & 0.9862 & 0.159437 & 0.2805 & -0.140152 & $0.0041 * * *$ \\
\hline Return & 0.00499059 & 0.6247 & -0.00315769 & 0.7313 & 0.00484825 & 0.3833 \\
\hline
\end{tabular}

Note: $* * 1 \%<p$-value $<5 \%$; *** $p$-value $<1 \%$ 
For the CASHETR and ETR measurements, none of the response variables show significant results. The constant and Ph.D. and Size variables are significant for CTAadj. These results indicate that the higher the CEO's level of education, the greater the company's tax aggressiveness, and the larger the company, the less tax aggressive it is.

\subsubsection{Corporate governance and ownership concentration}

Table 7 presents the results of the models with corporate governance variables that demonstrate significance in response to the measures of tax aggressiveness. Due to the perfect multicollinearity with the property concentration indexes, the results of this table also apply to the analysis of the possible effects of concentrated capital.

For the CASHETR and ETR measures, the Return variable is significant, indicating that greater tax aggressiveness is associated with a greater return on shares. In comparison, for the CTAadj measure, the constant and the Size variable are significant, indicating that larger companies are less tax aggressive.

The effect of property concentration was especially likely for the CASHETR model, but it was not significant; further, there are no other significant variables in that model. For the ETR model, the variable Return is significant, indicating greater tax aggressiveness generates a greater return on shares. For the CTAadj measure, the constant and the Size variable are significant, with the Size variable indicating larger companies are less tax aggressive. The Return variable is significant, indicating more tax-aggressive companies have a higher return on shares.

\subsubsection{Duality and turnover}

Table 8 presents the results of the tax aggressiveness models considering CEO duality and turnover in the sample companies.

Duality indicates independence between the chairman and the CEO, an appropriate corporate governance mechanism. For this reason, the expectation is that greater duality would result in less aggressiveness. Also, turnover represents the length of the CEO's term in the corporation: the longer the term, the less tax aggressiveness there would be.

No significant variables were found for the CASHETR and ETR models. For the CTAadj tax measure, the constant and the Size variable are

Table 7. Corporate governance

\begin{tabular}{|c|c|c|c|c|c|c|}
\hline \multirow{2}{*}{ Variables } & \multicolumn{2}{|c|}{ CASHETR } & \multicolumn{2}{|c|}{ ETR } & \multicolumn{2}{|c|}{ CTAadj } \\
\hline & Coefficient & $p$-value & Coefficient & $p$-value & Coefficient & $p$-value \\
\hline Const & 0.553186 & 0.5847 & -2.25077 & 0.2560 & 2.56839 & $0.0510^{*}$ \\
\hline OverConfidence & 0.195385 & 0.6284 & -0.293634 & 0.3160 & -0.0390633 & 0.9486 \\
\hline$M B$ & -0.00401091 & 0.4667 & 0.00318493 & 0.7904 & 0.000270884 & 0.971 \\
\hline Size & -0.0268295 & 0.6936 & 0.171313 & 0.1960 & -0.157905 & $0.0712 *$ \\
\hline Return & 0.00014464 & $5.47 \mathrm{E}-09 * * *$ & 0.00024556 & $<0.0001^{* * *}$ & $9.23026 \mathrm{E}-05$ & 0.8634 \\
\hline
\end{tabular}

Note: ${ }^{*} 5 \%<p$-value $<10 \% ; * * * p$-value $<1 \%$.

Table 8. Duality and turnover

\begin{tabular}{|c|c|c|c|c|c|c|}
\hline \multirow{2}{*}{ Variables } & \multicolumn{2}{|c|}{ CASHETR } & \multicolumn{2}{|c|}{ ETR } & \multicolumn{2}{|c|}{ CTAadj } \\
\hline & Coefficient & $p$-value & Coefficient & $p$-value & Coefficient & $p$-value \\
\hline Const & 0.355421 & 0.2673 & -1.51564 & 0.7009 & 2.36365 & $0.0045^{* * *}$ \\
\hline OverConfidence & -0.245840 & 0.3579 & 0.00586376 & 0.9902 & 0.321577 & 0.3682 \\
\hline CEO_Duality & 0.0235172 & 0.7963 & -0.0994584 & 0.6647 & -0.00772502 & 0.6772 \\
\hline CEO_Turnover & -0.0189001 & 0.6089 & -0.138984 & 0.4434 & 0.000912754 & 0.8506 \\
\hline$M B$ & 0.00689234 & 0.1798 & 0.014934 & 0.3883 & 0.00252732 & 0.2673 \\
\hline Size & -0.0141520 & 0.5392 & 0.132461 & 0.6109 & -0.144692 & $0.0084^{* * *}$ \\
\hline Return & 0.00635947 & 0.5559 & -0.000836677 & 0.9178 & 0.00586827 & 0.3497 \\
\hline
\end{tabular}

Note: $* * * p$-value $<1 \%$. 
Table 9. Stationarity

\begin{tabular}{|c|c|c|c|c|c|c|}
\hline \multirow{2}{*}{ Variables } & \multicolumn{2}{|c|}{ CASHETR } & \multicolumn{2}{|c|}{ ETR } & \multicolumn{2}{|c|}{ CTAadj } \\
\hline & Coefficient & $p$-value & Coefficient & $p$-value & Coefficient & $p$-value \\
\hline Tax aggressiveness & -0.749198 & $<0.0001 * * *$ & -0.0144100 & 0.7316 & 0.0673323 & $0.0038 * * *$ \\
\hline Const & 0.0110498 & 0.8319 & -0.0168573 & 0.8393 & 0.00330126 & 0.451 \\
\hline OverConfidence & 0.38894 & 0.8058 & -0.913344 & 0.7811 & 0.0544429 & 0.7509 \\
\hline $\mathrm{MB}$ & -0.000385043 & 0.9923 & 0.00172695 & 0.967 & 0.000853074 & 0.7047 \\
\hline Size & -0.342434 & 0.3842 & 0.43707 & 0.4697 & -0.281828 & $<0.0001^{* * *}$ \\
\hline Return & -0.000379796 & 0.7766 & 4.74E-05 & 0.9859 & 0.000108747 & 0.4335 \\
\hline
\end{tabular}

Note: $* * * p$-value $<1 \%$.

significant, with the Size variable indicating that a larger company size corresponds to less tax aggressiveness.

\subsubsection{Stationarity}

There is a possibility that overconfidence and tax aggressiveness may not occur in the same period, or that tax aggressiveness is a characteristic that does not depend on other variables. One way to measure the exogeneity of tax aggressiveness is by regressing the variable itself with its coefficients from the previous period. The results in all models analyzed suggest that current tax aggressiveness is significantly influenced by tax aggressiveness in previous periods, varying only in the direction of the association (Table 9).

For the CASHETR and CTAadj measures, the time-adjusted variable is significant; however, the interpretation of these measures differs. For CASHETR, the time-lagged variable indicates an inverse relationship with the current variable, which means that the company tends to decrease aggression after a year with intense tax aggressiveness. For CTAadj, the time-adjusted variable suggests a direct relationship, indicating increasing tax aggressiveness.

\section{DISCUSSION}

The results found in the main model contradict the conclusions of other researchers, in which it shows that overconfidence affects corporate taxation (Chyz et al., 2015; Aliani et al., 2016; Kubick \& Lockhart, 2017; Gul et al., 2018; Anjani, 2018; Hsieh et al., 2018).

Aliani et al. (2016) and Kubick and Lockhart (2017) use overconfidence metrics that differ from the measurement used in this research, which is why different results can be justified. The overconfidence literature indicates at least three ways to measure overconfidence: self-report measures, financial measures, and measures based on press releases (Aliani et al., 2016; Hayward \& Hambrick, 1997; Malmendier \& Tate, 2005; Schrand \& Zechman, 2012; Brown \& Sarma, 2007; Hill et al., 2014; Kubick \& Lockhart, 2017). However, Chyz et al. (2015), Gul et al. (2018), and Anjani (2018) use financial measures, such as CEO spending on capital goods acquisitions or stock options and find significant results for the association between overconfidence and tax aggressiveness.

Also, Aliani et al. (2016), and Anjani (2018) use $E T R$ as a measure of tax aggressiveness, while Kubick and Lockhart (2017) use the SHELTER measure. Chyz et al. (2015) and Gul et al. (2018) use several measures of tax aggressiveness to investigate its association with overconfidence, including CASHETR, TAX SHELTER, BTD, and GAAP ETR.

Besides, none of the other explanatory variables prove significant for the CASHETR tax aggressiveness measure. For the ETR measure, the only significant variable is the return on shares (Return). The analysis of this result indicates that the more taxed a company is, the greater the return on shares. Finally, concerning the CTAadj measure, the explanatory variables Size and return on shares (Return) are significant. The Size variable is significant for explaining tax aggressiveness: the larger the company's size, the less tax aggressive it is. The Return variable is significant, suggesting the more tax-aggressive a company is, the greater its return on shares. These results partially confirm the results of Hsieh et al. (2018) on corporate govern- 
ance variables. The present research finds significance for return on shares in the ETR and CTAadj models, confirming the results of Hsieh et al. (2018). However, the Size variable, which is significant in the CTAadj model, contradicts the results found by Hsieh et al. (2018), who states that there is no explanatory significance for that variable.
Finally, the results of the CASHETR and ETR models, indicating stationarity with a negative association, may indicate that Brazilian corporations have a tax target, possibly analogous to that suggested by capital structure trade-off theory. If such evidence is confirmed, a new research field in taxation may be opened related to the optimal taxation structure.

\section{CONCLUSION}

The present study examined the association between tax aggressiveness and overconfidence in a sample of 277 Brazilian corporations for over eight years. The assumption was that there would be a positive association between tax aggressiveness and overconfidence, considering the theory of the optimal structure of capital ownership since tax aggressiveness can result from the misalignment of the interests of managers and investors, with the former assuming higher tax risk increasing the variable portion of their compensation at the expense of creating long-term value for investors. However, this hypothesis cannot be confirmed given the lack of significance observed in the various models and specifications used for the data analysis, including those in most of the robustness.

The theoretical implications could indicate that sample corporations have corporate governance mechanisms that appropriately align the interests of managers and investors. Since the results show no association between tax aggressiveness and excess risk-taking by managers, tax aggressiveness would create value for investors.

This possibility becomes more robust considering the stationarity of the tax aggressiveness variables. This suggests corporations have an optimal taxation structure that, in theory, would maintain taxation at levels investors accept and that allow the corporation to continue to create value. Therefore, this supposedly optimal tax structure can become a useful field for theoretical development in future research.

Concomitantly, this evidence was obtained from an analysis of the data's stationarity, which also enables directly applying time-series econometric techniques to future studies. Using time-series econometrics would have the same impact as adopting the overconfidence variable proposed in this study by combining the variables that have been individually and less accurately examined in the literature.

There are obvious limitations in the present study. Although the tax measures used are almost standard in the literature on tax aggressiveness, there is a possibility, albeit mitigated, that the measures fail to adequately capture the concept. Again, this is a relevant methodological issue that should be addressed in future studies.

\section{AUTHOR CONTRIBUTIONS}

Conceptualization: Giovana Carrer, Tiago Slavov.

Data curation: Giovana Carrer, Tiago Slavov.

Formal analysis: Giovana Carrer, Tiago Slavov.

Investigation: Giovana Carrer, Tiago Slavov.

Methodology: Giovana Carrer, Tiago Slavov.

Project administration: Giovana Carrer.

Resources: Giovana Carrer.

Software: Giovana Carrer. 
Supervision: Tiago Slavov.

Validation: Giovana Carrer, Tiago Slavov.

Visualization: Giovana Carrer, Tiago Slavov.

Writing - original draft: Giovana Carrer.

Writing - review \& editing: Giovana Carrer, Tiago Slavov.

\section{REFERENCES}

1. Aliani, K., Mhamid, I., \& Rossi, M. (2016). Does CEO overconfidence influence tax planning? Evidence from Tunisian context. International Journal of Managerial and Financial Accounting, 8(3-4), 197-208. https://doi.org/10.1504/ IJMFA.2016.081851

2. Alicke, M. D., Klotz, M. L., Breitenbecher, D. L., Yurak, T. J., \& Vredenburg, D. S. (1995). Personal contact, individuation, and the better-than-average effect. Journal of Personality and Social Psychology, 68(5), 804-825. https://doi. org/10.1037/0022-3514.68.5.804

3. Anjani, F. T. (2018). The effect of board of directors' diversity and overconfidence on tax avoidance. Jurnal Ilmiah Mahasiswa FEB, 6(2). Retrieved from http:// jimfeb.ub.ac.id/index.php/jimfeb/ article/view/4686 (accessed on 27 November 2020).

4. Annuar, H. A., Salihu, I. A., \& Obid, S. N. S. (2014). Corporate ownership, governance and tax avoidance: An interactive effects. Procedia - Social and Behavioral Sciences, 164(December), 150-160. https://doi.org/10.1016/j.sbspro.2014.11.063

5. Armstrong, C. S., Blouin, J. L., \& Larcker, D. F. (2012). The incentives for tax planning. Journal of Accounting and Economics, 53(1-2), 391-411. https://doi.org/10.1016/j. jacceco.2011.04.001

6. Banerjee, S., Dai, L., HumpheryJenner, M., \& Nanda, V. (2020). Governance, board inattention, and the appointment of overconfident CEOs. Journal of Banking and Finance, 113(April), 105733. https://doi.org/10.1016/j.jbankfin. 2019.105733

7. Berle, A. A., \& Means, G. C. (1991). The Modern Corporation \& Private Property (2nd ed.). New
York: Routledge. Retrieved from https://www.taylorfrancis.com/ books/9781351479356 (accessed on 26 November 2020).

8. Boone, J. P., Khurana, I. K., \& Raman, K. K. (2013). Religiosity and tax avoidance. Journal of the American Taxation Association, 35(1), 53-84. https://doi. org/10.2308/atax-50341

9. Brown, R., \& Sarma, N. (2007). CEO overconfidence, CEO dominance and corporate acquisitions. Journal of Economics and Business, 59(5), 358-379. https://doi.org/10.1016/j.jeconbus.2007.04.002

10. Chen, J., Leung, W. S., Song, W., \& Goergen, M. (2019). Why female board representation matters: The role of female directors in reducing male $\mathrm{CEO}$ overconfidence. Journal of Empirical Finance, 53(September), 70-90. https://doi. org/10.1016/j.jempfin.2019.06.002

11. Chen, Y. R., Ho, K. Y., \& Yeh, C. W (2020). CEO overconfidence and corporate cash holdings. Journal of Corporate Finance, 62(June), 101577. https://doi.org/10.1016/j. jcorpfin.2020.101577

12. Christensen, D. M., Dhaliwal, D. S., Boivie, S., \& Graffin, S. D. (2015). Top management conservatism and corporate risk strategies: Evidence from managers' personal political orientation and corporate tax avoidance. Strategic Management Journal, 36, 19181938. https://doi.org/10.1002/ smj. 2313

13. Chyz, J. A. (2013). Personally tax aggressive executives and corporate tax sheltering. Journal of Accounting and Economics, 56(2-3), 311-328. https://doi.org/10.1016/j. jacceco.2013.09.003

14. Chyz, J. A., Gaertner, F. B., Kausar, A., \& Watson, L. (2015). Overconfi- dence and aggressive corporate tax policy. Proceedings. Annual Conference on Taxation and Minutes of the Annual Meeting of the National Tax Association, 107, 1-47. https:// doi.org/10.2139/ssrn.2408236

15. Dalcero, K., Fabrício, S. A., \& Ferreira, D. D. M. (2020). Mulheres como CFO (Chief Financial Officer) e CEO (Chief Executive Officer): Qual a Influência do Gênero na Qualidade dos Accruals? In XX USP International Coference in Accounting (Vol. 28, pp. 1-19). São Paulo, SP, Brasil.

16. Desai, M. A., \& Dharmapala, D. (2006). Corporate tax avoidance and high-powered incentives. Journal of Financial Economics, 79(1), 145-179. https://doi. org/10.1016/j.jfineco.2005.02.002

17. Dyreng, S. D., Hanlon, M., \& Maydew, E. L. (2008). Longrun corporate tax avoidance. The Accounting Review, 83(1), 61-82. https://doi.org/10.2308/ accr.2008.83.1.61

18. Dyreng, S. D., Mayew, W. J., \& Williams, C. D. (2012). Religious social norms and corporate financial reporting. Journal of Business Finance \& Accounting, 39(7-8), 845-875. https://doi.org/10.1111/ j.1468-5957.2012.02295.x

19. Feller, A., \& Schanz, D. (2017). The three hurdles of tax planning: How business context, aims of tax planning, and tax manager power affect tax expense. Contemporary Accounting Research, 34(1), 494-524. https://doi.org/10.2139/ ssrn. 2512177

20. França, R. D., \& Monte, P. A. (2018). Efeitos da reputação corporativa na tax avoidance de empresas brasileiras de capital aberto. Congresso ANPCONT. 
21. Francis, B., Hasan, I., Wu, Q., \& Yan, M. (2014). Are female CFOs less tax aggressive? Evidence from tax aggressiveness. American Accounting Association, 36(2), 171-202. https://doi.org/10.2308/ atax-50819

22. Gietl, D., \& Kassner, B. (2020). Managerial Overconfidence and Bank Bailouts. Journal of Economic Behavior \& Organization, 179(November), 202-222. https:// doi.org/10.1016/j.jebo.2020.08.019

23. Gul, F. A., Khedmati, M., \& Shams, S. M. M. (2018). Managerial acquisitiveness and corporate tax avoidance. Pacific Basin Finance Journal, 64(December), 101056. https://doi.org/10.1016/j.pacfin.2018.08.010

24. Hanlon, M., \& Heitzman, S. (2010). A review of tax research. Journal of Accounting and Economics, 50(2-3), 127-178. https://doi. org/10.1016/j.jacceco.2010.09.002

25. Hayward, M. L. A., \& Hambrick, D. C. (1997). Explaining the premiums paid for large acquisitions: Evidence of CEO hubris. Administrative Science Quarterly, 42(1), 103-127. https:/doi. org/10.2307/2393810

26. Hill, A. D., Kern, D. A., \& White, M. A. (2014). Are we overconfident in executive overconfidence research? An examination of the convergent and content validity of extant unobtrusive measures. Journal of Business Research, 67(7), 1414-1420. https://doi org/10.1016/j.jbusres.2013.08.011

27. Hsieh, T. S., Wang, Z., \& Demirkan, S. (2018). Overconfidence and tax avoidance: The role of CEO and CFO interaction. Journal of Accounting and Public Policy, 37(3), 241-253. https:// doi.org/10.1016/j.jaccpubpol.2018.04.004

28. Hwang, H. D., Kim, H. D., \& Kim, T. (2020). The blind power: Powerled CEO overconfidence and M\&A decision making. The North American Journal of Economics and Finance, 52(April). https://doi. org/10.1016/j.najef.2019.101141

29. Ignacio, S. da S. (2018). A formação de grupos empresariais como estratégia de planejamento tributário e seu efeito no valor das empresas (Tese de doutorado). Faculdade de Economia, Administração e Contabilidade de Ribeirão Preto, Universidade de São Paulo, Ribeirão Preto, SP, Brasil.

30. Jensen, M. C., \& Meckling, W. H. (1976). Theory of the firm: Managerial behavior, agency costs and ownership structure. Journal of Financial Economics, 3(4), 305360. https://doi.org/10.1016/0304405X(76)90026-X

31. Koester, A., Shevlin, T., \& Wangerin, D. (2017). The role of managerial ability in corporate tax avoidance. Management Science, 63(10), 3285-3310. https://doi. org/10.1287/mnsc.2016.2510

32. Kubick, T. R., \& Lockhart, G. B. (2017). Overconfidence, CEO awards, and corporate Tax aggressiveness. Journal of Business Finance \& Accounting, 44(5-6), 728-754. https://doi.org/10.1111/ jbfa. 12237

33. Langer, E. J. (1975). The illusion of control. Journal of Personality and Social Psychology, 32(2), 311-328. https://doi.org/10.1037//00223514.32.2.311

34. Law, K. K. F., \& Mills, L. F. (2017). Military experience and corporate tax avoidance. Review of Accounting Studies, 22, 141-184. https:// doi.org/10.1007/s11142-0169373-Z

35. Lopo Martinez, A., \& Salles, A. F. (2018). Agressividade tributária e cash holdings: um estudo das companhias abertas brasileiras. Revista de Contabilidade Da UFBA 12(3), 4. https://doi.org/10.9771/ rc-ufba.v12i3.24890

36. Malmendier, U., \& Tate, G. (2005). CEO overconfidence and corporate investment. Journal of Finance, 60(6), 2661-2700. https://doi.org/10.1111/j.15406261.2005.00813.x

37. March, J. G., \& Shapira, Z. (1987). Managerial perspectives on risk and risk taking. Management Science, 33(11), 1404-1418. https:// doi.org/10.1287/mnsc.33.11.1404

38. Olsen, K. J., \& Stekelberg, J. (2016). CEO narcissism and corporate tax sheltering. The Journal of the American Taxation Association, 38(1), 1-22. https://doi. org/10.2308/atax-51251

39. Schrand, C. M., \& Zechman, S. L. C. (2012). Executive overconfidence and the slippery slope to financial misreporting. Journal of Accounting and Economics, 53(1-2), 311-329. https://doi.org/10.1016/j. jacceco.2011.09.001

40. Slemrod, J. (2004). The economics of corporate tax selfishness. $\mathrm{Na}$ tional Tax Journal, 62(4), 877-899. Retrieved from http://www.nber. org/papers/w10858

41. Titman, S., \& Wessels, R. (1988). The Determinants of Capital Structure Choice. The Journal of Finance, 43(1), 1-19. https://doi. org/10.1111/j.1540-6261.1988. tb02585.x

42. Tseng, C., \& Demirkan, S. (2020). Joint effect of CEO overconfidence and corporate social responsibility discretion on cost of equity capital. Journal of Contemporary Accounting \& Economics, 17(1), 100241. https://doi.org/10.1016/j. jcae.2020.100241

43. Weinstein, N. D. (1980). Unrealisitic optimism about future life events. Journal of Personality and Social Psychology, 39(5), 806-820. https://doi.org/10.1037/00223514.39.5.806

44. Wilde, J. H., \& Wilson, R. J. (2018). Perspectives on corporate tax planning: Observations from the past decade. Journal of the American Taxation Association, 40(2), 63-81. https://doi.org/10.2308/ atax-51993 